УДК 616.314.7-008.1-06:616.441-008.6

DOI 10.11603/2311-9624.2018.1.8611

(С. в. Щерба, М. М. Корда

ДВНЗ «Тернопільський державний медичний університет імені І. Я. Горбачевського»

\title{
Роль дисфункції щитоподібної залози у патогенезі генералізованого пародонтиту (огляд літератури)
}

Резюме. Ендокринні захворювання є актуальною медико-соціальною проблемою сучасного суспільства. Зміни діяльності щитоподібної залози неминуче позначаються на різних системах організму, в тому числі й на функції і морфології органів і тканин порожнини рота.

Мета дослідження - на основі аналізу літературних даних визначити вплив дисфункції щитоподібної залози на перебіг хронічних запальних захворювань пародонта.

Матеріали і методи. У дослідженні використано бібліосемантичний та аналітичний методи.

Результати досліджень та іх обговорення. У статті викладено сучасні дані щодо перебігу хронічного генералізованого пародонтиту в умовах гіпер- та гіпотиреозу. На даний момент не існує остаточної думки щодо впливу тиреоїдних гормонів на кістковий метаболізм, оскільки доведено дуалізм їх ефектів. Різні дослідження показують неоднозначні дані щодо метаболічних змін у тканинах пародонта на тлі дисфункції щитоподібної залози.

Висновки. Аналіз результатів досліджень науковців свідчить про те, що дисфункція щитоподібної залози негативно впливає на перебіг хронічних запальних захворювань пародонта. Незважаючи на велику кількість досліджень, молекулярні механізми впливу тиреоїдних гормонів на кістковий метаболізм загалом та стан тканин пародонта зокрема, вивчено не повністю.

Ключові слова: дисфункція щитоподібної залози; пародонтит.

\section{(C). В. Щерба, М. М. Корда}

ГВУЗ «Тернопольский государственный медицинский университет имени И. Я. Горбачевского»

\section{Роль дисфункции щитовидной железы в патогенезе генерализированного пародонтита (обзор литературы)}

Резюме. Эндокринные заболевания являются актуальной медико-социальной проблемой современного общества. Изменения деятельности щитовидной железы неизбежно сказываются на различных системах организма, в том числе и на функции и морфологии органов и тканей полости рта.

Цель исследования - на основе анализа литературных данных определить влияние дисфункции щитовидной железы на течение хронических воспалительных заболеваний пародонта.

Материалы и методы. В исследовании использованы библиосемантичный и аналитический методы. Результаты исследований и их обсуждение. В статье изложены современные данные о ходе хронического генерализованного пародонтита в условиях гипер- и гипотиреоза. На данный момент не существует окончательного мнения относительно влияния тиреоидных гормонов на костный метаболизм, поскольку доказан дуализм их эффектов. Различные исследования показывают неоднозначные данные по метаболических изменениях в тканях пародонта на фоне дисфункции щитовидной железы.

Выводы. Анализ результатов исследований ученых свидетельствует о том, что дисфункция щитовидной железы негативно влияет на течение хронических воспалительных заболеваний пародонта. Несмотря на большое количество исследований, молекулярные механизмы влияния тиреоидных гормонов на костный метаболизм в целом и состояние тканей пародонта в частности, изучены не полностью.

Ключевые слова: дисфункция щитовидной железы; пародонтит. 
(C). V. Shcherba, M. M. Korda

I. Horbachevsky Ternopil State Medical University

\section{The role of the thyroid gland dysfunction in the pathogenesis of generalized parodontitis (review of literature)}

Summary. Endocrine diseases are an actual medical and social problem of modern society. Changes in the activity of the thyroid gland inevitably affect the various systems of the organism, including the function and morphology of the organs and tissues of the oral cavity.

The aim of the study - to determine the influence of thyroid gland dysfunction on the course of chronic inflammatory diseases of the periodontium, based on the analysis of the literature data.

Materials and Methods. The bibliosemantic and analytical methods have been used.

Results and Discussion. The article presents modern data on the course of chronic generalized periodontitis in case of hyperthyroidism and hypothyroidism. At the moment there is no definitive opinion regarding the influence of thyroid hormones on bone metabolism, since the duality of their effects is proved. Various studies show ambiguous data on metabolic changes in periodontal tissues in case of dysfunction of the thyroid gland. Conclusions. An analysis of the results of research by scientists suggests that dysfunction of the thyroid gland adversely affects the course of chronic inflammatory diseases of the periodontium. Despite the large number of studies, the molecular mechanisms of the influence of thyroid hormones on bone metabolism in general and the state of periodontal tissues, in particular, have not been completely studied.

Key words: dysfunction of thyroid gland; periodontitis.

Вступ. Ендокринні захворювання є актуальною медико-соціальною проблемою сучасного суспільства [1-5]. За офіційними даними В003, близько 1,5 млрд людей на сьогодні страждає від захворювань щитоподібної залози. Незважаючи на успіхи медицини в лікуванні ендокринних захворювань, кількість хворих із кожним роком лише збільшується $[6,7]$.

Дисфункцію щитоподібної залози спостерігають у 30-40 \% пацієнтів 3 ендокринологічною патологією. Американська асоціація клінічних ендокринологів заявила, що в США приблизно 13 млн людей або 4,78 \% популяції мають недіагностовану патологію щитоподібної залози [8].

Середня поширеність дисфункції щитоподібної залози в Європі становить 3,82 \%. Поширеність попередньо діагностованого та недіагностованого гіпотиреозу та гіпертиреозу становить 3,05 та 0,75 \% відповідно. При цьому 85,2 \% випадків дисфункції щитоподібної залози є субклінічними. Захворюваність на патологію щитоподібної залози в Європі становить 259,12 на 100000 населення на рік. При цьому явно переважають жінки: 419,72 на 100000 на рік відносно 85,36 на 100000 на рік для жінок і чоловіків відповідно [9].

У структурі загальної захворюваності населення України ендокринна патологія скла- ла 4,5 \%, серед якої провідне місце належить патології щитоподібної залози - 46,4 \% [10]. В Україні за останні 5 років кількість хворих із дисфункцією щитоподібної залози збільшилася у 5 разів. На диспансерному обліку перебувають 3,5 млн осіб, 70 \% населення страждають від дефіциту йоду. Найчастіше діагностують зоб I-III ступенів - у 66,2 \% хворих, вузлові форми зоба - в 12,7 \%, тиреоїдити (аутоімунний, гострий, підгострий) - у 8,4 \%, гіпотиреоз - у 7,9 \%, дифузний токсичний зоб - в 2,9 \%, рак - у 1,7 \% хворих [11-13]. У дітей в Україні патологія щитоподібної залози посідає перше місце серед ендокринних хвороб і займає 58,0 \% їх структури, головним чином, за рахунок дифузного зоба I ступеня. Поширеність тиреоїдної дисфункції в різних регіонах України іноді коливається в десятки разів. Причиною таких розбіжностей $є$ не лише вплив певних екологічних чинників, а, головним чином, якість діагностування і реєстрації захворювань [14].

Метою дослідження було на основі аналізу літературних даних визначити вплив дисфункції щитоподібної залози на перебіг хронічних запальних захворювань пародонта.

Матеріали і методи. У дослідженні використано бібліосемантичний та аналітичний методи.

Результати досліджень та їх обговорення. Зміни діяльності щитоподібної залози

ISSN 2311-9624. Клінічна стоматологія. 2018. № 1 
неминуче позначаються на різних системах організму, в тому числі й на функції і морфології органів та тканин порожнини рота. Щитоподібна залоза робить важливий внесок у регуляцію усіх видів метаболізму, особливо енергетичних процесів, що відбиваються на тканинах пародонта [15-17].

За даними Т. Р. Сутаєвої та співавт., порушення функції щитоподібної залози ускладнює перебіг хронічного генералізованого пародонтиту, причому більш тяжкий характерний для хворих на гіпотиреоз. Так, при ендемічному зобі у фазі еутиреозу пародонтит легкого ступеня тяжкості виявляють у 16,7 \% випадків, середнього ступеня тяжкості - в 53,3 \%, а тяжкого - 30,0 \%; при ендемічному зобі у фазі гіпотиреозу пародонтит легкого ступеня тяжкості практично не виявляють, середнього ступеня тяжкості був в 40,0 \% випадків, а тяжкого - в 60,0 \% [15].

Провівши аналіз стоматологічного статусу пацієнтів із захворюваннями щитоподібної залози, Т. В. Павлова та співавт. встановили, що у 18 пацієнтів із 40 був наявний парадонтит: 11 - легкої форми, 5 - середньої, 2 - тяжкої. У контрольній групі тільки 10 пацієнтів мали пародонтит. При дослідженні рентгенограм пацієнтів виявлено резорбцію кортикальних пластинок і зниження висоти міжзубних перегородок у 45 \% випадків, що підтверджує наявність пародонтиту, в контрольній групі 25 \%. Причому в пацієнтів із гіпертиреозом пародонтит був у $50 \%$ випадків (10 осіб), в осіб із гіпотиреозом - у 40 \% (8 осіб) [18].

За даними О. В. Деньги, найчутливішою до зміни рівня гормонів щитоподібної залози є нижня щелепа [19]. Дослідження Н. С. Мельник [20] свідчать про зниження мінеральної щільності передпліччя й альвеолярного відростка (з прямим кореляційним зв'язком середньої сили між показниками) у пацієнтів iз гіпотиреозом. Автор розглядає цей факт як один з патогенетичних механізмів розвитку хронічного генералізованого пародонтиту в даного контингенту.

У роботі М. В. Козлової [21] вивчено причини атрофії альвеолярної частини і відростка щелеп при остепенічному синдромі у хворих із патологією щитоподібної залози. Було продемонстровано, що низька активність тиреоїдних гормонів у пацієнтів гальмувала кісткоутворення опосередковано, викликаючи тенденцію до зниження рівня кальцитоніну i помірно підвищуючи виділення паратгормо- ну, що сприяло посиленій продукції фактора некрозу пухлин-а (TNF- $\alpha$ ), прозапальних цитокінів IL-6, IL-1, що активують остеокластогенез і знижують функцію остеобластів.

Зміни в тканинах пародонта при експериментальному гіпотиреозі мають стереотипний характер: дистрофічні, атрофічні й деструктивні зміни паренхіматозних структур, муцинозний набряк строми, слабко виражені репаративні процеси. Дані зміни при дефіциті гормонів щитоподібної залози зумовлені зниженням рівня основного обміну, уповільненням окиснювально-відновних процесів, «метаболічною депресією» i, як наслідок, гіпоксією тканин. У результаті порушення росту і диференціювання клітин та тканин відбувається уповільнення фізіологічної регенерації. Надлишок глюкозамінгліканів змінює колоїдну структуру тканин, підсилює їх гідрофільність, що призводить до набухання і розпушування колагенових волокон. При цьому хромотропні речовини вивільняються із зв'язків з білками і накопичуються переважно в міжклітинній речовині з подальшим заміщенням колагенових волокон слизоподібними масами. У результаті муцинозного набряку проміжної речовини відбувається стиснення клітин, дистрофія, некробіоз, некроз і атрофія. Ці зміни бувають в епітелії і власній пластинці слизової оболонки, в шарі одонтобластів, у пульпі зуба, в тканинах періодонта [22].

Цікавими є дослідження Н. А. Кореневської та I. В. Городоцької [23], в яких показано, що експериментальний стрес на тлі пригнічення функції щитоподібної залози мерказолілом спрчинив виражені порушення стану тканин пародонта - підвищення ступеня рецесії ясен, атрофію альвеолярного відростка, рухомість зубів. Було виявлено захисну дію малих доз тироксину відносно білязубних тканин при хронічному стресі. В основі цього, на думку авторів, лежить стимуляція йодтиронінами синтезу високоспецифічних клітинних білків, у тому числі тих, що входять до складу локальних стрес-лімітуючих систем, насамперед білків теплового шоку. Крім цього, має значення антиоксидантна дія йодтиронінів, зниження йодтиронінами інтенсивності стрессиндрому, нормалізація балансу протеїнази/ інгібітори протеїназ, стимулюючий вплив тиреоїдних гормонів на гемоциркуляцію, імунну систему організму.

Дослідження О. Л. Шнейдер [24] показали, що хронічний генералізований пародонтит 
у пацієнтів із первинним гіпотиреозом характеризується пролонгованим латентним перебігом 3 клінічними проявами у вигляді поєднання генералізованої рецесії ясен, вираженої втрати клінічного прикріплення. У пародонтальних кишенях в пацієнтів із гіпотиреозом визначали всі п'ять маркерних пародонтопатогенів. Достовірно вищою була частота виявлення пародонтопатогену Prevotella intermedia.

Кісткова тканина є динамічною структурою, що постійно оновлюється та перебуває під контролем великої кількості системних і місцевих факторів, серед яких важливу роль відіграють саме гормони щитоподібної залози. Сучасні дослідження довели дуалізм ефектів тиреоїдних гормонів на кістковий метаболізм. 3 одного боку, трийодтиронін шляхом прямого впливу на остеобласти і хондроцити стимулює остеогенез. 3 іншого боку, через опосередковані механізми впливу на остеокласти трийодтиронін ініціює резорбцію кісткової тканини [19]. Дія тиреоїдних гормонів опосередковується рецепторами гормонів щитоподібної залози (TR), котрі кодуються генами THRA і THRB [25]. Розрізняють декілька видів тиреоїдних рецепторів: TRa1, TRa2, TRß1 та TRß2 [26]. Вони локалізуються не лише на тиреоцитах, але й на більшості людських клітин. Лише TR $\beta 2$ пов'язаний із гіпоталамусом і гіпофізом, де гальмує секрецію ТРГ і ТTГ. Експресія рецепторів у кістці безпосередньо свідчить, що ця тканина знаходиться під впливом тиреоїдних гормонів. Остеобласти та хондроцити мають на своїй поверхні обидва види рецепторів - TR $\alpha$ і TR $\beta$, але чисельність TRa1 рецепторів у 10 разів перевищує кількість TRß1-рецепторів [26]. TRa1 розглядають як основний функціональний медіатор впливу трийодтироніну на скелет [27]. Біологічна роль TRa2 залишається невідомою. $€$ дані, що трийодтиронін бере участь у регуляції хондрогенезу та кісткової мінералізації. Він стимулює IL-6 та IL-8, посилює ефекти IL-1 та IL-6, підвищує синтез остеокальцину, колагену типу I, збільшує проліферацію, диференціювання та апоптоз остеобластів [28].

Під час формування кістки Т3 стимулює проліферацію, диференціювання та апоптоз остеобластів і збільшує експресію остеокальцину, колагену типу I, лужної фосфатази, металопротеїнів, IGF-1 та його рецептора (IGF-1R). Згодом, під час резорбції кістки, Т3 збільшує експресію важливих факторів диференціювання остео- кластів, таких, як інтерлейкін-6 і простагландин E2. Простагландини, особливо PGE2, є потужними мультифункціональними регуляторами кісткового метаболізму. PGE2 зумовлює морфологічні зміни в остеобластах і остеокластах через збільшення внутрішньоклітинного рівня циклічного аденозинмонофосфату [29].

Крім того, Т3 діє синергічно з остеокластогенними гормонами, такими, як паратиреоїдний гормон і вітамін D. Також було продемонстровано, що Т3 збільшує експресію мРНК ліганда рецепторного активатора ядерного фактора-к $\beta$ (RANKL) в остеобластах, що активує RANK, наявний у попередниках остеокластів [30].

I. М. Піксін та співавт. стверджують, що тироксин володіє набагато меншою спорідненістю до рецепторів тиреоїдних гормонів і впливом на клітини кісткового метаболізму [31]. 3а іншими даними, Т4 володіє вираженою резорбтивною дією. Він прямо може впливати на кісткове ремоделювання, пришвидшує остеокластичну активність, стимулюючи виділення простагландинів [32].

Аналогічно, експресія ТТГ-рецепторів (TSHR) була продемонстрована в остеобластах та остеокластах, що свідчить про те, що ТТГ може мати прямий вплив на ці клітини [26]. Деякі автори заявляють, що ТТГ відіграє важливу роль у метаболізмі кісткової тканини, яка не залежить від дій тиреоїдних гормонів [30]. Інші наукові дані свідчать про те, що ТТГ розглядається як негативний регулятор «кісткового обороту». Його пряма дія на клітини кісткової тканини призводить до підвищення ремоделювання кісток та остеопорозу [33].

Остеокальцин - це кальційзв'язувальний білок кісткової тканини з невеликою молекулярною масою (5,4 kDa), вміст якого становить 10-20 \% від усіх неколагенових білків кісткового матриксу [34]. Остеокальцин синтезується зрілими остеобластами, остеоцитами та одонтобластами та вважається найпоширенішим неколагеновим білком кісткового матриксу, що специфічний для кісткової тканини та дентину. Він розглядається як один 3 найінформативніших біохімічних маркерів формування кісткової тканини та швидкості «кісткового обороту» [35]. Остеокальцин, що циркулює в крові, - результат синтезу de novo, а не вивільнений при резорбції кісткової тканини, тому за його рівнем можна оцінити метаболічну активність остеобластів [36].

Що стосується змін концентрації остеокальцину в зубоясенній рідині за умови пародон- 
титу, то дані літератури є суперечливими. Так, K. Kunimatsu та співавт. не визначили підвищення рівня остеокальцину в зубоясенній рідині пацієнтів із гінгівітом, проте встановили позитивні кореляційні зв'язки між концентрацією остеокальцину в зубоясенній рідині й клінічними параметрами у пацієнтів із пародонтитом [37].

A. J. Lee та співавт. продемонстрували аналогічні рівні остеокальцину в зубоясенній рідині на уражених і здорових ділянках у пацієнтів із хронічним пародонтитом [38].

A. N. Wilson та співавт. не вдалося виявити остеокальцин у зубоясенній рідині пацієнтів із нелікованим пародонтитом [39].

3 іншого боку, Nakashima та співавт. [40] виявили підвищений рівень остеокальцину в зубоясенній рідині на ділянках із пародонтитом відносно неуражених ділянок та уражених гінгівітом.

У дослідженні S. Becerik та співавт. встановлено зниження рівня остеокальцину за умови пародонтиту відносно здорових пацієнтів. Більш того рівень остеокальцину в зубоясенній рідині негативно корелював 3 клінічними параметрами у пацієнтів із пародонтитом [34]. ці дані можуть вказувати на патологічний «кістковий оборот» за умови пародонтиту.

Н. С. Мельник обстежила 192 хворих на генералізований пародонтит хронічного перебігу із дисфункцією щитоподібної залози, яких поділили на 3 групи: перша - 68 осіб із супутнім гіпертиреозом, друга - 64 пацієнти із супутнім гіпотиреозом, які приймали L-тироксин у дозах 50-75 мкг/добу, третя - 60 осіб із супутнім гіпотиреозом, які тривало приймали препарат L-тироксин у дозах понад 100 мкг/добу. Показники рівня остеокальцину в сироватці крові в контрольній групі (генералізований пародонтит) були в межах норми. Рівень остеокальцину в першій групі (супутній гіпертиреоз) у хворих на генералізований пародонтит був незначно підвищений. У пацієнтів другої групи (супутній гіпотиреоз) із генералізованим пародонтитом рівень остеокальцину був знижений. У хворих першої групи зміни у пародонті мали виражений запальний характер, що проявлялося особливо високими показниками індексів PМА та кровоточивості й більшою кількістю людей, уражених генералізованим пародонтитом II та III ступенів розвитку. У другій групі генералізований пародонтит проявлявся суттєвими дистрофічнозапальними змінами, а також рентгенологіч- ного індексу рецесіі. У третій групі виявлено ще більш виражені дистрофічно-запальні зміни, що є вищими, ніж при менш інтенсивному лікуванні гіпотиреозу [41, 42].

$€$ дані, що у пацієнтів із запальними і запально-дистрофічні захворюваннями парадонта на тлі захворювань щитоподібної залози превалюють метаболічні порушення у тканинах пародонта [43-45]. В осіб із захворюваннями пародонта і гіпофункцію щитоподібної залози спостерігається патологічна зміна обмінних процесів, підвищення протеолітичної активності крові, посилення екскреції мінеральних компонентів, особливо кальцію і фосфору [44]. Порушення обміну мінеральних речовин призводить до того, що у всіх хворих на дифузний токсичний зоб навіть на ранній стадії захворювання наявні запально-дистрофічні зміни в пародонті [45].

Т. С. Москвіна та співавт. при експериментальному гіпо- та гіпертиреозі встановили залежність тяжкості ураження пародонта від стану неспецифічної резистентності, яка більш суттєво знижується при гіпотиреозі. Дослідження пародонта у тварин показало більш ранні й виражені патологічні запальнодеструктивні зміни при гіпотиреозі [46].

Захворювання пародонта на тлі гіпотиреозу характеризуються розвитком хронічного запального процесу разом із вираженим зниженням обміну кальцію в кістковій тканині альвеолярного відростка щелеп. У хворих із післяопераційним гіпотиреозом визначались виражені запальні зміни в тканинах пародонта 3 утворенням глибоких кісткових кишень, кровоточивістю ясен, серозно-гнійним ексудатом, рецидивним перебігом. Патологічний процес у тканинах пародонта від початку розвитку захворювання мав схильність до хронічного, в'ялого перебігу на тлі сухості порожнини рота, підвищеної в'язкості слини, а також супроводжувався інтенсивним відкладанням зубного каменя, збільшенням показників порівняно з тиреотоксикозом [47].

Депо кальцію і фосфору представлено кістковою тканиною, що відіграє важливу роль у підтриманні постійної концентрації цих елементів у крові. Біологічно активною є фракція іонізованого кальцію, а білково-зв'язаний кальцій і його комплексні фракції метаболічно інертні та є «запасними» для швидкої, при необхідності трансформації в іонізований кальцій. 90-99 \% внутрішньоклітинного кальцію припадає на кальцій, локалізований 
у мітохондріях і мікросомах, де він знаходиться у зв'язаній формі з органічними і неорганічними фосфатами. У цитоплазмі кальцій зв'язаний 3 кальмодуліном. Концентрація фосфору контролюється менш жорстко, ніж концентрація кальцію. Внутрішньоклітинна концентрація фосфору становить близько половини позаклітинної. Рух фосфору через клітинну мембрану пасивний і визначається в основному потоком кальцію [48].

Кальцій - це іон, який найінтенсивніше вивчався як потенційний маркер захворювань пародонта у слині [49]. L. Sewón та M. Mäkelä у своїх дослідженнях показали, що концентрація кальцію у слині була підвищена і співвідношення кальцію до фосфору було також вищим в осіб, які страждають від захворювань пародонта, i, таким чином, було зроблено висновок, що підвищена концентрація кальцію в слині є характерною для пацієнтів із пародонтитом [50].

М. С. Зяблицкая та В. Г. Атрушкевич стверджують, що кальцієвий гомеостаз у пацієнтів із хронічним генералізованим пародонтитом характеризується підвищеним рівнем іонізованого кальцію порівняно 3 контрольними значеннями. Рівень загального кальцію в сироватці крові при цьому не змінювався [51].

О. А. Успенська та Є. С. Качесова вивчали особливості обміну кальцію і фосфору при лікуванні швидкопрогресуючого пародонтиту. Результати дослідження показали, що рівень загального кальцію в крові до лікування швидкопрогресуючого пародонтиту був у межах норми. Вміст іонізованого кальцію в крові був більше схильним до змін. Рівень фосфору в крові пацієнтів із швидкопрогресуючим пародонтитом був достовірно вищим $(\mathrm{p}<0,001)$ від рівня контрольної групи [52].

При порушенні кальцій-фосфорного обміну відбувається втрата мінеральних компонентів, унаслідок чого зменшується кісткова маса скелета, що сприяє зниженню висоти міжзубної перегородки і порушенню прикріплення ясен i, як наслідок, прогресуванню пародонтиту [18].

За даними I. М. Піксіна, в разі підвищення концентрації тиреоїдних гормонів при захворюваннях щитоподібної залози спостерігається прискорення процесів кісткового моделювання - кісткоутворення і резорбції кісткової тканини, 3 переважанням останньої. Це зумовлює розвиток остеопенії і остеопорозу та дисбаланс кальцій-фосфорного гомеостазу у вигляді гіпокальціємії, гіперфосфатемії, гіперкальційурії. У пацієнтів із гіпотиреозом, навпа- ки, спостерігається уповільнення кісткового метаболізму, сповільнюються процеси резорбції і кісткоутворення, рівні кальцію та фосфору в крові й сечі залишаються не змінними [31].

У хворих на пародонтит i гіпофункцію щитоподібної залози спостерігається патологічна зміна обмінних процесів, посилення екскреції мінеральних компонентів, особливо кальцію і фосфору [43].

N. M. Dolidze та співавт. показали, що субклінічна форма гіпотиреозу не була пов'язана зі значними змінами вмісту $\mathrm{Ca}^{2+}$ в остеобластах та плазмі крові. Прогресування гіпотиреозу та розвиток клінічних ознак захворювання супроводжувалися зменшенням вмісту $\mathrm{Ca}^{2+}$ в остеобластах та плазмі крові на 45 і $12 \%$ відповідно. Гіпертиреоз характеризувався помірним зниженням вмісту $\mathrm{Ca}^{2+}$ у плазмі крові на $15 \%$ [32].

$€$. $€$. Конопля встановила, що навіть за умови медикаментозної компенсації гіпотиреозу виявлено зниження рівня співвідношення кальцію-фосфору в слині та сечі, переважання патології пародонта з надмірним утворенням зубних відкладень. У пацієнтів із гіпотиреозом найчастіше спостерігаються кровоточивість ясен, зміни складу слини і зубного нальоту, патологічна рухомість зубів, розвиток пародонтиту і патології твердих тканин зуба [53].

У дослідженні М. В. Вербової та співавт. 3 боку фосфорно-кальцієвого обміну в молодих жінок із тиреотоксикозом виявлені: гіпокальціємія, гіперфосфатемія, збільшення екскреції кальцію з сечею, підвищення рівня паратгормону [54].

О. А. Павленко та співавт. досліджували остеопенічний синдром у пацієнтів із патологією щитоподібної залози. Було виявлено спряженість гіперпродукції гормонів щитоподібної залози з тенденцією до негативного кальцієвого балансу. Рівень кальцію в крові у хворих на тиреотоксикоз збільшився, порівняно $з$ показниками контрольної групи, але без статистично значущої різниці. Зазначалося підвищення екскреції кальцію з сечею у 14 випадках (34,14 \%). Рівень фосфору в крові у хворих на тиреотоксикоз не змінився відносно показників контрольної групи. Рівень кальцію і фосфору в крові у пацієнтів із маніфестним гіпотиреозом і субклінічним гіпотиреозом не відрізнялися від контрольних значень. Зниження рівня тиреоїдних гормонів не привело до зміни екскреції кальцію з сечею у осіб із маніфестним і субклінічним гіпотиреозом [55]. 
За умови гіпертиреозу відбувається пряма стимуляція кісткових клітин за рахунок високої концентрації тиреоїдних гормонів. Про гіперкальціємію повідомляють приблизно у 23 \% випадків гіпертиреозу. Відсоток гіперкальціємії при гіпертиреозі збільшується до 50 \% при вимірюванні концентрації іонізованого кальцію замість загального вмісту кальцію в сироватці крові [56].

При гіпотиреозі може знижуватися вміст кальцію у крові через порушену мобілізацію кальцію в кісткову тканину. Проте D. Mendez та співавт. встановили, що у гіпотиреоїдних осіб показники загального кальцію та іонізованого кальцію достовірно не відрізнялися відносно контрольної еутиреоїдної групи [56]. На противагу цьому, Е. Е. Hassan та співавт. показали виражене зниження рівня загального кальцію у гіпотиреоїдних пацієнтів [57]. Виражене зменшення концентрації іонізовано- го кальцію та нормальний рівень загального кальцію за умови гіпотиреозу показав у своєму дослідженні H. K. Al-Hakeim [58].

Висновки. Аналіз результатів досліджень науковців свідчить про те, що дисфункція щитоподібної залози негативно впливає на перебіг хронічних запальних захворювань пародонта. Незважаючи на велику кількість досліджень, молекулярні механізми впливу тиреоїдних гормонів на кістковий метаболізм загалом та стан тканин пародонта зокрема, вивчено не повністю.

Перспективи подальших досліджень. Дослідження в даному напрямку дозволять встановити найчутливіші діагностичні й прогностичні критерії тяжкості ураження пародонта за умови дисфункції щитоподібної залози та поліпшити лікувально-профілактичні комплекси для корекції проявів генералізованого пародонтиту в даної групи осіб.

\section{Список літератури}

1. Кравченко В. І.Динаміка захворюваності на патологію щитоподібної залози в Україні / В. І. Кравченко, С. В. Постол // Международный эндокринологический журнал. - 2011. - № 3 (35). - С. 56-59.

2. Тимків В. В. Статистичний аналіз непухлинних захворювань щитоподібної залози в Івано-Франківській області протягом 2007-2011 pр. / В. В. Тимків // Галицький лікарський вісник. - 2014. - Т. 21, № 1. С. $96-100$.

3. Йодный статус и дозы облучения щитовидной железы у пострадавших вследствие Чорнобыльской катастрофы, проживающих в Северных регионах Украины (украинско-американское когортное исследование) / Н.Д. Тронько, К. Мабучи, В. И. Кравченко [и др.] // Журнал НАМН України. - 2013. - Т. 19, № 3. - С. 355-364.

4. Тактика лечения диффузного токсического зоба / Б. Х. Бебезов, М. А. Нуралиев, Т. Т. Какчекаеева [и др.] // Клиническая медицина. - 2013. - № 9. - С. 61-67.

5. Rugge J. B. Screening and treatment of thyroid dysfunction: An evidence review for the U.S. preventive services task force / J. B. Rugge, C. Bougatsos, R. Chou // Annals of Internal Medicine. - 2015. - Vol. 162, No. 1. Р. 35-46.

6. Владимирова I. М. Фармакотерапевтичні напрямки застосування йодовмісних лікарських рослин при різних групах захворювань щитоподібної залози / I. М. Владимирова, В. А. Георгіянц // Scientific Journal «ScienceRise». - 2015. - № 11/4(16). - C. 46-54. 7. 2012 ETA Guidelines: The Use of L-T $4+$ L-T 3 in the Treatment of Hypothyroidism / W. M. Wiersinga, L. Duntas, V. Fadeyev [et al.] // European Thyroid Journal. - 2012. - Vol. 1. - P. 55-71.

8. Clinical practice guidelines for hypothyroidism in adults: cosponsored by the American Association of Clinical Endocrinologists and the American Thyroid As- sociation / J. R. Garber, R. H. Cobin, H. Gharib [et al.] // Endocrine Practice Journal. - 2012. - Vol. 18. - P. 9881028.

9. The incidence and prevalence of thyroid dysfunction in Europe: A meta-analysis / Ane Garmendia Madariaga, Silvia Santos Palacios, Francisco Guillén-Grima [et al.] // The Journal of Clinical Endocrinology and Metabolism. 2014. - Vol. 99. - P. 923-931.

10. Динаміка інвалідності хворих на гіпотиреоз у Тернопільській області за період 2013-2015 рр. / В. С. Вернигородський, Н. М. Фетісова, М. В. Вернигородська [та ін.] // Вісник соціальної гігієни та організації охорони здоров’я України. - 2017. - № 3 (73). C. 12-15.

11. Оценка состояния липидного обмена при дисфункции щитовидной железы / В. Г. Каджарян, А. И. Мельник, П. П. Бидзиля, А. О. Соловьюк // Запорожский медицинский журнал. - 2014. № 1 (82). - C. 20-22.

12. Фадеев В. В. Заболевания щитовидной железы. Проблемы эндокринологии / В. В. Фадеев, Г. А. Мельниченко. - К. : Высшая наука, 2011. - С. 7-14.

13. Гайдаев Ю. О. Состояние эндокринологической службы Украины в 2010 г. и подходы к развязке проблемных вопросов / Ю. О. Гайдаев, Р. О. Моисеенко // Международный эндокринологический журнал. 2011. - № 2 (8). - С. 13-17.

14. Зелінська Н. Б. Патологія щитоподібної залози у дитячого населення України / Н. Б. Зелінська, О. С. Ларін // Клінічна ендокринологія та ендокринна хірургія. - 2016. - № 3 (55). - С. 76-81.

15. Хронический генерализованный пародонтит у больных эндемическим зобом / Т. Р. Сутаева, С. Р. Минкаилова, И. М. Шамов, О. Г. Омаров // Вестник новых медицинских технологий. - 2012. - Т. 19, № 3. - C. 46-47. 
16. Zahid T. M. The effects of thyroid hormone abnormalities on periodontal disease status / T. M. Zahid, B. Y. Wang, R. E. Cohen // Journal of the International Academy of Periodontology. - 2011. - Vol. 13 (3). P. 80-85.

17. Fabue L. C. Dental management of patients with endocrine disorders / L. C. Fabue, Y. J. Soriano, M. G. S. Pérez // Journal of Clinical and Experimental Dentistry. - 2010. Vol. 2 (4). - P. 196-203.

18. Павлова Т. В. Клинические наблюдения и анализ стоматологического статуса пациентов с заболеваниями щитовидной железы / Т. В. Павлова, Э. К. Пешкова, Д. А. Колесников // Фундаментальные исследования. - 2012. - № 4. - С. 97-100.

19. Деньга О. В. Роль тиреоидных гормонов в интегральной регуляции костного метаболизма в норме и при гипотиреозе (обзор литературы) / О. В. Деньга, К. А. Колесник // Таврический медико-биологический вестник. - 2012. - Т.15, № 1 (57). - С. 332-337.

20. Структурно-функціональний стан кісткової тканини у хворих на генералізований пародонтит 3 супутнім захворюванням щитовидної залози / Н. С. Мельник, I. П. Мазур, В. М. Рижик [та ін.] // Архів клінічної медицини. - 2008. - № 2. - С. 31-34.

21. Козлова М. В. Атрофия альвеолярной части и отростка челюстей при остепеническом синдроме у больных с патологией щитовидной железы и гипогонадизмом (современные методы диагностики и лечения) : автореф. дисс. на соискание уч. степени д. мед. наук : спец. 14.00.21 «Стоматология», 14.00.03. «Эндокринология» / М. В. Козлова. - М., 2009. - 32 с. 22. Оганян А. В. Клинико-морфологические изменения зубо-челюстной системы при гипотиреозе : автореф. дисс. на соискание уч. степени канд. мед. наук : спец. 14.00.21 «Стоматология», 14.03.02 «Патологическая анатомия» / А. В. Оганян. - Ставрополь, 2010. - 22 с.

23. Кореневская Н. А. Состояние тканей маргинального периодонта при хроническом стрессе зависит от тиреоидного статуса организма / Н. А. Кореневская, И. В. Городецкая // Вестник Витебского государственного медицинского университета. - 2010. - Т.9, № 1. - С. 1-11.

24. Цитоморфометрические показатели при хроническом генерализованном пародонтите у пациентов с первичным гипотиреозом / О. Л. Шнейдер [и др.] // Институт стоматологии. - 2008. - № 3. - С. 78-79.

25. The skeletal consequences ofthyrotoxicosis / J. Nicholls, M. Brassil, G. Williams, J. Bassett // Journal of Endocrinology. - 2012. - No. 213. - P. 209-211.

26. Gorka J. Metabolic and clinical consequences of hyperthyroidism on bone density / J. Gorka, R. Taylor-Gjevre, T. Arnason // International Journal of Endocrinology. - 2013. - P. 638-727.

27. Basset J. The skeletal phenotypes of TRa and TR $\beta$ mutant mice / J. Basset, G. Williams // Journal of Molecular Endocrinology. - 2009. - No. 42. - P. 269-282. 28. Tuchendler D. The influence of thyroid dysfunction on bone metabolism / D. Tuchendler, M. Bolanowski // Thyroid Research. - 2014. - No. 7. - P. 12.

29. Effect of cyclical forces on the periodontal ligament and alveolar bone remodeling during orthodontic tooth movement / Z. Kalajzic, E. B. Peluso, A. Utreja [et al.] // The Angle Orthodontist. - 2014. - No. 84. - P. 297-303.
30. Cardoso L. F. The multiple effects of thyroid disorders on bone and mineral metabolism / L. F. Cardoso, L. M. Z. Maciel, F. J. A. de Paula // Arquivos Brasileiros de Endocrinologia \& Metabologia - 2014. - No. 58 (5). P. $452-463$.

31. Состояние костного метаболизма при заболеваниях щитовидной железы (обзор) / И. Н. Пиксин, В. И. Давыдкин, А. С. Московченко [и др.] // Медицинский альманах. - 2016. - № 4 (44). - С. 154-157.

32. Dolidze N. M. Changes in intra- and extracellular $\mathrm{Ca} 2+$ concentration and prostaglandin E2 synthesis in osteoblasts of the femoral bone in experimental hyper- and hypothyroidism / N. M. Dolidze, D. D. Kezeli, L. O. Kilasoniya // Bulletin of Experimental Biology and Medicine. - 2007. - No. 144. - P. 17-20.

33. Weak evidence of thyrotropin receptors in primary cultures of human osteoblast-like cells / J. Tsai, A. Janson, E. Bucht [et al.] // Calcified Tissue International. - 2004. No. 74. - P. 486-491.

34. Gingival crevicular fluid calprotectin, osteocalcin and cross-linked N-terminal telopeptid levels in health and different periodontal diseases / S. Becerik, B. Afacan, V. Ö. Oztürk [et al.] // Disease Markers. - 2011. - No. 31. P. 343-352.

35. Дрок В. О. Визначення показників метаболізму кісткової тканини у пацієнтів з зубощелепними аномаліями та остеопенічним синдромом / В. О. Дрок // Вісник проблем біології і медицини. 2015. - T. 2, № 2 (119). - С. 79-82.

36. Галкина О. П. Уровень маркеров костного метаболизма у подростков с генерализованным пародонтитом, на фоне деформаций позвоночника / О. П. Галкина // Вісник стоматології. - 2013. - № 3. - С. 30-33.

37. A cross-sectional study on osteocalcin levels in gingival crevicular fluid from periodontal patients / K. Kunimatsu, S. Mataki, H. Tanaka [et al.] // Journal of Periodontology. - 1993. - No. 64. - P. 865-869.

38. Gingival crevicular fluid osteocalcin in adult periodontitis / A. J. Lee, T. F. Walsh, S. J. Hodges, A. Rawlinson // Journal of Clinical Periodontology. 1999. - No. 26. - P. 252-256.

39. Bone turnover markers in serum and periodontal microenvironments / A. N. Wilson, M. J. Schmid, D. B. Marx, R. A. Reinhardt // Journal of Periodontal Research. - 2003. - No. 38. - P. 355-361.

40. Nakashima K. Osteocalcin, prostaglandin E2 and alkaline phosphatase in gingival crevicular fluid: Their relations to periodontal status / K. Nakashima, N. Roehrich, G. Cimasoni // Journal of Clinical Periodontology. - 1994. - No. 21. - P. 327-333.

41. Мельник Н. С. Маркери ремоделювання кісткової тканини у хворих на генералізований пародонтит із супутнім гіпо- і гіпертиреозом / Н. С. Мельник, А. С. Мельник // TEMPUS: електронне наукове фахове видання. - Електронні дані. - [Запоріжжя : ЗДМУ]. - С. 109-110. - Режим доступу: http://dspace. zsmu.edu.ua/bitstream/123456789/3842/1/15_lyst_TEM PUS_\%D0\%97\%D0\%94\%D0\%9C\%D0\%A3_109-110.pdf (дата звернення 23.11.2017 р.). - Назва з екрана.

42. Мельник Н. С. Оцінка показників пародонтального статусу у хворих на генералізований пародонтит на тлі порушення функції щитоподібної залози / Н. С. Мельник // Галицький лікарський вісник. 2013. - T. 20, № 3. - С. 50-52. 
43. Проданчук А. І. Захворювання пародонта і соматична патологія / А. I. Проданчук, І. Д. Кіюн, М. О. Кройтор // Буковинський медичний вісник. 2012. - Т. 16, № 2 (62). - С. 164-168.

44. Шнейдер О. Л. Заболевания пародонта при гипофункции щитовидной железы (обзор) / О. Л. Шнейдер, В. П. Журавлев // Урал. - 2004. - № 6. - С. 31-32.

45. Кристаллографическое исследование смешанной нестимулированой слюны у пациентов с диффузным токсическим зобом / С. Н. Денисенко, А. А. Шапашникова, С. С. Григорьев [и др.] // Проблемы стоматологии. - 2005. - № 2. - С. 739.

46. Состояние пародонта и неспецифической резистентности в динамике експериментального гипо- и гипертиреоза / Т. С. Москвина, Л. И. Иванова, В. Н. Каплин [и др.] / Стоматология. - 1993. - № 3. - С. 4-7. 47. Курякина Н. В. Заболевания пародонта / Н. В. Курятина. - М. : Медицинская книга, 2007. - 292 с.

48. Масалова Н. Н. Состояние фосфорно-кальциевого обмена и костного метаболизма в норме и при нарушении функции щитовидной железы / Н. Н. Масалова, Р. В. Захаренко // Дальневосточный медицинский журнал. - 2009. - № 2. - С. 122-125.

49. Grover H. S. Periodontal proteomics: Wonders never cease / H. S. Grover, S. Kapoor, N. Saksena // International Journal of Proteomics. - 2013. - doi:10.1155/2013/850235. 50. Sewón L.A study of the possible correlation of high salivary calcium levels with periodontal and dental conditions in young adults / L. Sewón, M. Mäkelä // Archives of Oral Biology. - 1990. - Vol. 35, No. 1. P. 211-212.

51. Зяблицкая М. С. Патогенетические основы развития генерализованного пародонтита на фоне нарушения метаболизма кальция и витамина D / М. С. Зяблицкая, В. Г. Атрушкевич // Інновації в стоматологіï. - 2014. - № 1. - С. 24-28.

\section{References}

1. Kravchenko, V.I. \& Postol, S.V. (2011). Dynamika zakhvoriuvanosti na patolohiiu shchytopodibnoi zalozy $\mathrm{v}$ Ukraini [The dynamics of morbidity in pathology of thyroid gland in Ukraine]. Mezhdunarodnyy Endokrinologicheskiy zhurnal - International Endocrinology Journal, 3 (35), 56-59 [in Ukrainian].

2. Tymkiv, V.V. (2014). Statystychnyi analiz nepukhlynnykh zakhvoriuvan shchytopodibnoi zalozy v Ivano-Frankivskii oblasti protiahom 2007-2011 rr. [Statistical analysis of non-tumor diseases of the thyroid gland in Ivano-Frankivsk region during 2007-2011]. Halytskyi likarskyi visnyk - Galician Medicinal Herald, 21 (1), 96-100 [in Ukrainian].

3. Tronko, N.D., Mabuchi, K. \& Kravchenko V.I. (2013). Iodnyy status i dozy oblucheniya shchitovidnoy zhelezy u postradavshikh vsledstvie Chornobylskoy katastrofy, prozhivayushchikh $\mathrm{v}$ Severnykh regionakh Ukrainy (ukrainsko-amerikanskoe kogortnoe issledovanie) [Iodine status and doses of thyroid irradiation in victims of the Chornobyl disaster living in the Northern regions of Ukraine (Ukrainian-American cohort study)]. Zhurnal NAMN Ukrainy - Journal of the National Academy of Medical Sciences of Ukraine, 19 (3), 355-364 [in Russian]. 4. Bebezov, B.Kh., Nuraliev, M.A. \& Kakchekaeeva, T.T. (2013). Taktika lecheniiy diffuznogo toksicheskogo zoba
52. Успенская О. А. Изменения биохимических показателей крови при лечении быстропрогрессирующего пародонтита / О. А. Успенская, Е. С. Качесова // Проблемы стоматологии. - 2017. - Т. 13, № 2. - С. 33-38. 53. Конопля Е. Е. Стоматологический статус и кальциево-фосфорный обмен у больных с патологией щитовидной и паращитовидных желез (Медицинские последствия аварии на ЧАЭС) : автореф. дисс. на соискание уч. степени канд. мед. наук : 14.00.21 / Конопля Евгения Евгеньевна. - М., 2002. $24 \mathrm{c}$.

54. Вербовая М. В. Минеральная плотность кости, показатели ее метаболизма и кальций-фосфорного обмена у больных тиреотоксикозом / М. В. Вербовая // Остеопороз и остеопатии. - 2002. - № 1. - С. 16-19.

55. Исследование остеопенического синдрома у пациентов с патологией щитовидной железы методом ультразвуковой остеометрии / О. А. Павленко, Л. Б. Ночевная, В. Д. Завадовская, О. Ю. Килина // Бюллетень сибирской медицины. - 2014. - Т. 13, № 2. - C. 31-37.

56. A comparative study of the ionic and total calcium levels in women with thyroid dysfunction / D. Mendez, M. Kunder, K. N. Shashidhar, L. Venkataswamy // International Journal of Medical Science and Public Health. - 2016. - Vol. 5 (04). - P. 633-637.

57. Assessment of serum levels of calcium and phosphorous in Sudanese patients with hypothyroidism/ E. E. Hassan, A. S. Ashmaik, H. M. Gabra, A. O. M. Elzein // Asian Journal of Biomedical and Pharmaceutical Sciences. - 2013. - Vol. 3 (25). - P. 21-26.

58. Al-Hakeim H. K. Serum levels of lipids, calcium and magnesium in women with hypothyroidism and cardiovascular diseases / H. K. Al-Hakeim // Journal of Laboratory Physicians. - 2009. - Vol. 1 (2). - P. 49-52.

[The tactics of treating diffuse toxic goiter]. Klinicheskaya meditsina - Clinical Medicine, 9, 61-67 [in Russian]. 5. Rugge, J.B., Bougatsos, C. \& Chou, R. (2015). Screening and treatment of thyroid dysfunction: an evidence review for the U.S. Preventive Services Task Force. Annals of Internal Medicine, 162, 1, 35-46.

6. Vladymyrova, I.M. \& Heorhiiants, V.A. (2015). Farmakoterapevtychni napriamky zastosuvannia yodovmisnykh likarskykh roslyn pry riznykh hrupakh zakhvoriuvan shchytopodibnoi zalozy [Pharmacotherapeutic directions of application of iodine-containing medicinal plants in different groups of diseases of the thyroid gland]. Scientific Journal «ScienceRise», 11, 4 (16), 46-54 [in Ukrainian].

7. Wiersinga, W.M., Duntas, L., Fadeyev, V., Nygaard, B. \& Vanderpump, M.P. (2012). 2012 ETA Guidelines: The Use of L-T 4 + L-T 3 in the Treatment of Hypothyroidism. European Thyroid Journal, 1, 55-71.

8. Garber, J.R., Cobin, R.H. \& Gharib, H. (2012). Clinical practice guidelines for hypothyroidism in adults: cosponsored by the American Association of Clinical Endocrinologists and the American Thyroid Association. Endocrine Practice Journal,18, 988-1028.

9. Madariaga, A.G., Palacios, S.S., Guillén-Grima, F. \& Galofré, J.C. (2014). The incidence and prevalence of 
thyroid dysfunction in Europe: a meta-analysis. The Journal of Clinical Endocrinology and Metabolism, 99, 923-931.

10. Vernyhorodskyi, V.S., Fetisova, N.M., Vernyhorodska, M.V., Valentieva, R.V. \& Malchenko, O.V. (2017). Dynamika invalidnosti khvorykh na hipotyreoz u Ternopilskii oblasti za period 2013-2015 rr. [Dynamics of disability of patients with hypothyroidism in the Ternopil region for the period of 2013-2015.]. Visnyk sotsialnoi hihiieny ta orhanizatsii okhorony zdorovia Ukrainy Bulletin of Social Hygiene and Health Care Organizations of Ukraine, 3 (73), 12-15 [in Ukrainian].

11. Kadzharian, V.G., Melnik, A.I., Bidzilya, P.P. \&. Solovyuk, A.O. (2014). Otsenka sostoyaniya lipidnogo obmena pri disfunktsii shchitovidnoy zhelezy [Assessment of the state of lipid metabolism in thyroid dysfunction]. Zaporozhskiy meditsinskiy zhurnal - Zaporozhye Medical Journal, 1 (82), 20-22 [in Russian].

12. Fadeev, V.V. \& Melnichenko, G.A. (2011). Zabolevaniya shchitovidnoy zhelezy. Problemy endokrinologii [Diseases of the thyroid gland. Problems of endocrinology]. Vysshaya nauka - Higher Science, 7-14 [in Russian]. 13. Gaydaev, Yu.O. \& Moyseenko, R.O. (2011). Sostoyanie endokrinologicheskoy sluzhby Ukrainy v 2010 g. i podkhody k razvyazke problemnykh voprosov [The state of endocrinology service of Ukraine in 2010 and approaches to the solution of problematic issues]. Mezhdunarodnyy endokrinologicheskiy zhurnal - International Endocrinology Journal, 2 (8), 13-17 [in Russian].

14. Zelinska, N.B. \& Larin, O.S. (2016). Patolohiia shchytopodibnoi zalozy u dytiachoho naselennia Ukrainy [Pathology of thyroid gland in the children's population of Ukraine]. Klinichna endokrynolohiia ta endokrynna khirurhiia - Clinical Endocrinology and Endocrine Surgery, 3 (55), 76-81 [in Ukrainian].

15. Sutaeva, T.R., Minkailova, S.R., Shamov, I.M. \& Omarov, O.G. (2012). Khronicheskiy generalizovannyy parodontit u bolnykh endemicheskim zobom [Chronic generalized periodontitis in patients with endemic goiter]. Vestnik novykh meditsinskikh tekhnologiy - Bulletin of New Medical Technologies, 19, 3, 46-47 [in Russian].

16. Zahid, T.M., Wang, B.Y. \& Cohen, R.E. (2011). The effects of thyroid hormone abnormalities on periodontal disease status. Journal of the International Academy of Periodontology, 13 (3), 80-85.

17. Fabue, L.C., Soriano, Y.J. \& Pérez, M.G.S. (2010). Dental management of patients with endocrine disorders. Journal of Clinical and Experimental Dentistry, 2 (4), 196-203.

18. Pavlova, T.V., Peshkova, E.K. \& Kolesnikov, D.A. (2012). Klinicheskie nablyudeniya i analiz stomatologicheskogo statusa patsientov s zabolevaniyami shchitovidnoy zhelezy [Clinical observations and analysis of the dental status of patients with thyroid disease]. Fundamentalnye issledovaniya - Basic Research, 4, 97-100 [in Russian]. 19. Denga, O.V., \& Kolesnik, K.A. (2012). Rol tireoidnykh gormonov v integralnoy regulyatsii kostnogo metabolizma v norme i pri gipotireoze [The role of thyroid hormones in the integrated regulation of bone metabolism in normal and hypothyroidism]. Tavricheskiy medikobiologicheskiy vestnik - Tavrichesky Medico-biological Journal, 15, 1 (57), 332-337 [in Russian].

20. Melnyk, N.S., Mazur, I.P. \& Ryzhyk, V.M. (2008). Strukturno-funktsionalnyi stan kistkovoi tkanyny u khvorykh na heneralizovanyi parodontyt z suputnim zakhvoriuvanniam shchytovydnoi zalozy [Structuralfunctional state of bone tissue in patients with generalized periodontitis with concomitant thyroid disease]. Arkhiv klinichnoi medytsyny - Archive of Clinical Medicine, 2, 31-34 [in Ukrainian].

21. Kozlova, M.V. (2009). Atrofiia alveoliarnoi chasti i otrostka chelyustey pri ostepenicheskom sindrome $u$ bolnykh s patologiey shchitovidnoy zhelezy i gipogonadizmom (sovremennye metody diagnostiki i lecheniya) [Atrophy of the alveolar part and process of the jaws in the osteopenic syndrome in patients with thyroid pathology and hypogonadism (modern methods of diagnosis and treatment)]. Extended abstract of Doctor's thesis. Moscow [in Russian].

22. Oganyan, A.V. (2010). Kliniko-morfologicheskie izmeneniya zubo-chelyustnoy sistemy pri gipotireoze [Clinical and morphological changes in the dento-jaw system with hypothyroidism]. Extended abstract of Doctor's thesis. Stavropol [in Russian].

23. Korenevskaya, N.A. \& Gorodetskaya, I.V. (2010). Sostoyanie tkaney marginalnogo periodonta pri khronicheskom stresse zavisit ot tireoidnogo statusa organizma [The condition of the marginal periodontal tissues under chronic stress depends on the thyroid status of the organism]. Vestnik Vitebskogo gosudarstvennogo meditsinskogo universiteta - Bulletin of Vitebsk State Medical University, 9, 1, 1-11 [in Russian].

24. Shneyder, O.L. (2008). Tsitomorfometricheskie pokazateli pri khronicheskom generalizovannom parodontite $\mathrm{u}$ patsientov s pervichnym gipotireozom [Cytomorphometric indices in chronic generalized periodontitis in patients with primary hypothyroidism]. Institut stomatologii - Institute of Stomatology, 3, 78-79 [in Russian]. 25. Nicholls, J., Brassil, M., Williams, G. \& Bassett, J. (2012). The skeletal consequences ofthyrotoxicosis. Journal of Endocrinology, 213, 209-211.

26. Gorka, J., Taylor-Gjevre, R. \& Arnason, T. (2013). Metabolic and clinical consequences of hyperthyroidism on bone density. International Journal of Endocrinology, 638-727.

27. Basset, J., \& Williams, G. (2009). The skeletal phenotypes of TRa and TR $\beta$ mutant mice. J. Mol. Endocrinol., 42, 269-282.

28. Tuchendler, D., \& Bolanowski, M. (2014). The influence of thyroid dysfunction on bone metabolism. Thyroid Research, 7, 12.

29. Kalajzic, Z., Peluso, E.B., Utreja, A., Dyment, N., Nihara, J., Xu, M. et al. (2014). Effect of cyclical forces on the periodontal ligament and alveolar bone remodeling during orthodontic tooth movement. Angle Orthod., 84, 297-303.

30. Cardoso, L.F., Maciel, L.M.Z., \& de Paula F.J.A. (2014). The multiple effects of thyroid disorders on bone and mineral metabolism. Arquivos Brasileiros de Endocrinologia \& Metabologia, 58/5, 452-463.

31. Piksin, I.N., Davyidkin, V.I. Moskovchenko, A.S., Vilkov, A.V. \& Kechaykin, A.N. (2016). Sostoyanie kostnogo metabolizma pri zabolevaniyakh shchitovidnoy zhelezy [The state of bone metabolism in diseases of the thyroid gland]. Meditsinskiy almanakh - Medical Almanac, 4 (44), 154-157 [in Russian].

32. Dolidze, N.M., Kezeli, D.D., \& Kilasoniya, L.O. (2007). Changes in intra- and extracellular $\mathrm{Ca} 2+$ concentra- 
tion and prostaglandin E2 synthesis in osteoblasts of the femoral bone in experimental hyper- and hypothyroidism. Bulletin of Experimental Biology and Medicine, 144, 17-20.

33. Tsai, J., Janson, A., Bucht, E., Kindmark, H., Marcus, C., Stark, A. et al. (2004). Weak evidence of thyrotropin receptors in primary cultures of human osteoblast-like cells. Calcified Tissue International, 74, 486-491.

34. Becerik, S., Afacan, B., \& Oztürk, V.Ö. (2011). Gingival crevicular fluid calprotectin, osteocalcin and cross-linked $\mathrm{N}$-terminal telopeptid levels in health and different periodontal diseases. Disease Markers, 31, 343-352.

35. Drok, V.O. (2015). Vyznachennia pokaznykiv metabolizmu kistkovoi tkanyny u patsiientiv z zuboshchelepnymy anomaliiamy ta osteopenichnym syndromom [Determination of bone metabolism in patients with dental anomalies and osteopenic syndrome]. Visnyk problem biolohii $i$ medytsyny - Journal of Biology and Medicine, 2, 2 (119), 79-82 [in Ukrainian].

36. Galkina, O.P. (2013). Uroven markerov kostnogo metabolizma u podrostkov s generalizovannym parodontitom, na fone deformatsiy pozvonochnika [The level of markers of bone metabolism in adolescents with generalized periodontitis, against the backdrop of deformities of the spine]. Visnyk stomatolohii - Journal of Dentistry, 3, 30-33 [in Russian].

37. Kunimatsu, K., Mataki, S., Tanaka, H., Mine, N., Kiyoki, M., Hosoda, K. et al. (1993). A cross-sectional study on osteocalcin levels in gingival crevicular fluid from periodontal patients. Journal of Periodontology, 64, 865-869.

38. Lee, A.J., Walsh, T.F., Hodges S.J., Rawlinson, A. (1999). Gingival crevicular fluid osteocalcin in adult periodontitis. Journal of Clinical Periodontology, 26, 252-256.

39. Wilson, A.N.,Schmid, M.J., Marx, D.B., \& Reinhardt, R.A. (2003). Bone turnover markers in serum and periodontal microenvironments. Journal of Periodontal Research, 38, 355-361.

40. Nakashima, K., Roehrich, N., \& Cimasoni, G. (1994). Osteocalcin, prostaglandin E2 and alkaline phosphatase in gingival crevicular fluid: Their relations to periodontal status. Journal of Clinical Periodontology, 21, 327-333. 41. Melnyk, N.S., \& Melnyk, A.S. Markery remodeliuvannia kistkovoi tkanyny u khvorykh na heneralizovanyi parodontyt iz suputnim hipo- i hipertyreozom [Markers of bone remodeling in patients with generalized periodontitis with concomitant hypo- and hyperthyroidism]. TEMPUS. dspace.zsmu.edu.ua. Retrieved from: http: // dspace. zsmu.edu.ua / bitstream /123456789/3842/1/15_lyst_TEMPUS_\%D0\%97\%D0\%94 \%D0\%9C\%D0\%A3_109-110.pdf [in Ukrainian].

42. Melnyk, N.S. (2013). Otsinka pokaznykiv parodontalnoho statusu u khvorykh na heneralizovanyi parodontyt na tli porushennia funktsii shchytopodibnoi zalozy [Evaluation of indicators of periodontal status in patients with generalized periodontitis in the background of thyroid disturbance]. Halytskyi likarskyi visnyk - Galician Medicinal Herald, 20, 3, 50-52 [in Ukrainian].

43. Prodanchuk, A.I., Kiiun, I.D., \& Kroitor, M.O. (2012). Zakhvoriuvannia parodonta i somatychna patolohiia [Periodontal disease and somatic pathology]. Bukovynskyi medychnyi visnyk - Bukovyna Medical Bulletin, 16, 2 (62), 164-168 [in Ukrainian].
44. Shneyder, O.L. \& Zhuravlev, V.P. (2004). Zabolevaniya parodonta pri gipofunktsii shchitovidnoy zhelezy (Obzor) [Periodontal diseases in thyroid hyperfunction (overview)]. Ural - Ural, 6, 31-32 [in Russian].

45. Denisenko, S.N., Shapashnikova, A.A. \& Grigorev, S.S. (2005). Kristallograficheskoe issledovanie smeshannoy nestimulirovanoy slyuny $\mathrm{u}$ patsientov s diffuznym toksicheskim zobom [Crystallographic study of mixed unstimulated saliva in patients with diffuse toxic goiter]. Problemy stomatologii - Problems of Dentistry, 2, 739 [in Russian].

46. Moskvina, T.S., Ivanova, L.I., Kaplin, V.N., Fefelov, A.I. \& Shilova, F.A. (1993). Sostoyanie parodonta i nespetsificheskoy rezistentnosti $\mathrm{v}$ dinamike eksperimentalnogo gipo- i gipertireoza [Condition of periodontal and nonspecific resistance in the dynamics of experimental hypo- and hyperthyroidism]. Stomatologiya - Stomatology, 3, 4-7 [in Russian].

47. Kuryakina, N.V. (2007). Zabolevaniya parodonta [Periodontal disease]. Meditsinskaya kniga - Medical Book, 292 [in Russian].

48. Masalova, N.N. \& Zakharenko, R.V. (2009). Sostoyanie fosforno-kaltsievogo obmena i kostnogo metabolizma v norme i pri narushenii funktsii shchitovidnoy zhelezy [The state of phosphorus-calcium metabolism and bone metabolism in norm and in violation of thyroid function]. Dalnevostochnyy meditsinskiy zhurnal - Far Eastern Medical Journal, 2, 122-125 [in Russian].

49. Grover, H.S., Kapoor, S. \& Saksena, N. (2013). Periodontal proteomics: Wonders never cease. International Journal of Proteomics. doi: 10.1155/2013/850235.

50. Sewón, L. \& Mäkelä, M. (1990). A study of the possible correlation of high salivary calcium levels with periodontal and dental conditions in young adults. Archives of Oral Biology, 35, 1, 211-212.

51. Ziablitskaya, M.S. \& Atrushkevich, V.G. (2014). Patogeneticheskie osnovy razvitiya generalizovannogo parodontita na fone narusheniya metabolizma kaltsiya i vitamina D [Pathogenetic bases of development of generalized periodontitis against a background of calcium and vitamin D metabolism disorders]. Innovatsii $v$ stomatologii - Innovations in Dentistry, 1, 2-28 [in Russian]. 52. Uspenskaya, O.A. \& Kachesova, E.S. (2017). Izmeneniya biokhimicheskikh pokazateley krovi pri lechenii bystroprogressiruyushchego parodontita [Changes in biochemical parameters of blood in the treatment of fast-progressive periodontitis]. Problemy stomatologii Problems of Dentistry, 13, 2, 33-38 [in Russian].

53. Konoplya, E.E. (2002). Stomatologicheskiy status i kaltsievo-fosfornyy obmen u bolnykh s patologiey shchitovidnoy i parashchitovidnykh zhelez (Meditsinskie posledstviya avarii na ChAES) [Dental status and calcium-phosphorus metabolism in patients with pathology of the thyroid and parathyroid glands (Medical consequences of the Chernobyl accident)]. Extended abstract of Doctor's thesis. Moscow [in Russian]. 54. Verbovaya, M.V. (2002). Mineralnaya plotnost kosti, pokazateli ee metabolizma i kaltsiy-fosfornogo obmena $\mathrm{u}$ bolnykh tireotoksikozom [Mineral density of bone, its metabolism and calcium-phosphorus metabolism in patients with thyrotoxicosis]. Osteoporoz i osteopatii Osteoporosis and Osteopathy, 1, 16-19 [in Russian].

55. Pavlenko, O.A., Nochevnaya, L.B., Zavadovskaya, V.D. \& Kilina, O.Yu. (2014). Issledovanie osteopenicheskogo 
sindroma $\mathrm{u}$ patsientov $\mathrm{s}$ patologiyey shchitovidnoy zhelezy metodom ultrazvukovoy osteometrii [Study of osteopenic syndrome in patients with thyroid pathology using ultrasonic osteometry]. Biulleten sibirskoy meditsiny - Bulletin of Siberian Medicine, 13, 2, 31-37 [in Russian].

56. Mendez, D., Kunder, M., Shashidhar K.N., Venkataswamy, L. (2016). A comparative study of the ionic and total calcium levels in women with thyroid dysfunction. International Journal of Medical Science and Public Health, 5 (04), 633-637.
57. Hassan, E.E., Ashmaik, A.S., Gabra, H.M. \& Elzein, A.O.M. (2013). Assessment of serum levels of calcium and phosphorous in Sudanese patients with hypothyroidism. Asian Journal of Biomedical and Pharmaceutical Sciences, 3 (25), 21-26.

58. Al-Hakeim, H.K. (2009). Serum levels of lipids, calcium and magnesium in women with hypothyroidism and cardiovascular diseases. Journal of Laboratory Physicians, 1 (2), 49-52.

Отримано 28.12.17 